\title{
Crisis in Black Theology: Reasserting a future based on spiritual liberative praxis
}

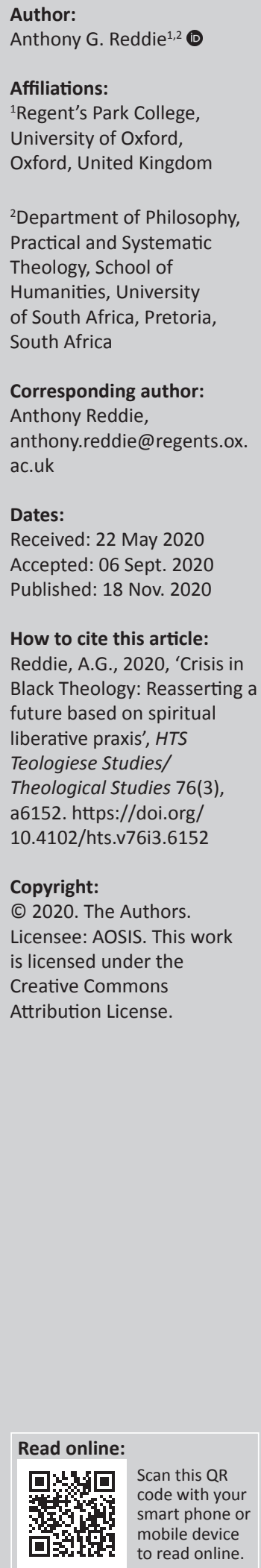

This study explores the contemporary crisis in Black Theology and its present moribund complexion. The author, a well-known black theologian, argues that Black Theology as an academic discipline has struggled with an identity crisis emerging from its origins as a pragmatic response to the existential struggles evinced in the lives of black people and not as an intellectual movement in the first instance. As sociopolitical contexts have changed, a number of scholars have posed the question as to whether there is a continued need for Black Theology. This study outlines the nature of the semantic challenges facing Black Theology and reflects on the importance of Black spirituality (an important theme in the work of Vuyani Vellem) as a means of enabling this form of liberative praxis to better connect to the lived experiences of ordinary black people.

Contribution: This article contributes to the ongoing development of black liberation theology across the world. The article focuses on three historic locations where Black theology has traditionally flourished, these being the United States, the United Kingdom and South Africa. In response to the necessity for Black Theology to better relate to the practical realities of ordinary underprivileged black people this article proposes that greater attention should be given to liberative, spiritual praxis.

Keywords: Black Theology; racism; existential challenges; internalised racism; colourism; dialectical spiritualities; Mission Christianity; liberative spiritual praxis.

\section{Introduction}

The author of this article is a leading black liberation theologian and decolonial educator in the United Kingdom (UK). This article is written in honour of the late great Vuyani Vellem. It is inspired by Vellem's legacy as opposed to a focussed piece of work on the precise nature of his scholarship per se. In this article, I am seeking to explore the contemporary challenge to the continuing praxis of Black Theology in three alternative contexts, namely, the United States of America (USA); the UK, where I am located; and South Africa, the context in which Vuyani Vellem excelled for so long. The purpose of this study is to explore the epistemological, thematic and methodological challenges facing Black Liberation Theology using the totemic figure of Vuyani Vellem as the catalyst for this diagnostic work, utilising reflections across three contexts as a means of accomplishing this task.

\section{The crisis in Black Theology}

One of the conceptual problems facing Black Theology lies in its very nomenclature - basically why 'Black Theology'? When I was undertaking my Viva Voce some 20 years ago now at the University of Birmingham, one of the first pressing questions asked to me by one of the examiners was 'is there such a thing as Black Theology', and if there is a Black Theology, then that presupposes that there is 'White Theology?' But there is no such thing as 'White Theology', so is there really such a thing as 'Black Theology?' The question felt less like a 'genuine question' than an accusation.

The question of whether there is, indeed, such a thing as Black Theology and whether it is desirable that such a thing should exist remains a contentious issue and is a challenge posed as much by some black people (see Anyabwile 2007; Bradley 2010; Carter 2016) as it is by their quizzical white peers. I recall some elements of this arising many years ago when I was a prominent member of the ‘Black Methodist Group' (BMG) within the British Methodist Church. The BMG was founded

Note: Special Collection entitled VukaniBantuTsohangBatho - Spirituality of Black Liberation, sub-edited by Fundiswa Kobo (UNISA) and Rothney Tshaka (UNISA). 
in the 1980s as a caucus group for black people to challenge and contest the endemic, institutional racism of our church. However, much like the contemporary crisis in the British Labour Party around 'Black Sections' in the 1980s, ${ }^{1}$ the movement towards a black-only caucus group was extremely controversial. For many, the existence of this group (as well as its counterpart in the British Labour Party) was seen as divisive and problematic. Some of the leading black people in British Methodism refused to join because the group would be perceived as separatist.

One of the major problems with the BMG, for many, was the sense that our association was predicated on the grounds of a conceptual folly in the first instance. What I mean by this statement is that the group was founded to fight racism in the church and beyond it. It is at this point that one of the basic constructions in Black Theology comes to the fore, namely, that problematic notion of 'race'.

In the materialistic sense, the concept of 'race' does not exist. A number of scholars have demonstrated the specious nature of such discourse and the ways in which it seeks to create untenable and unstable boundaries between groups of humanity (see Coates 2014; Eddo-Lodge 2017; Oluo 2018). In the words of the annual 'Racial Justice Sunday' packs of resource material produced by the 'Churches Commission for Racial Justice (CCRJ), "there is only one race - that is the human race"' (see Eze 1997; Hopkins 2005). Whilst 'race' is simply a problematic, conceptual idea, racism, the damnable 'offspring' of the notion of 'race', most definitely exists, that is, racism as the observable manifestation of the notion of 'race' can be seen in the demonstrable ways in which systems and structures of power are created and developed, which have a negative impact on the material experiences and opportunities of black and other people with darker skin in the world (see Ackroyd, Lewis-Cooper and Muchopa 2001, 2005; see also Muchopa 2001).

Black Theology was developed in order to respond to the very real challenges and threats posed to black peoples by the manifest evil of racism in the world. For some, the semantic question that surrounds Black Theology is (1) whether it should have ever existed (if the Christian west had lived out the basic propositions of the Christian faith, then surely there was no need for Black Theology to have ever been needed) and (2) whether its long-term viability can be assured.

In the first instance, some will argue that Black Theology only emerged because of the failings of others - that is, the white power structures of empire and Christendom. Paraphrasing a celebrated quote from the African American religious and cultural critic, Victor Anderson (1995), is Black Theology dependent on the blackness that whiteness created?

The intellectual conundrum that lies at the heart of this discourse is that without the horrors of the slave trade, colonialism and racism, there would be no need for Black Theology. So, in effect, Black Theology is an aberrant discipline with no natural identity in and of itself (Reddie 2006). Linked to the first question is naturally the second one, namely, does Black Theology have a future? When I was being interviewed for my former role as a research fellow at the Queen's Foundation, one of the first questions from the black conservative Pentecostal interviewer was 'And what happens to Black Theology when racism is defeated and no longer exists?'

It can be argued that the aforementioned challenges have exerted a negative impact on the very identity and substantive underscoring of the discipline itself (Reddie 2006). In order to amplify this contention, I would like to draw our attention to the three principal locations in which Black Theology is undertaken in order to see something of this phenomenon in practice.

\section{Black Theology in the United States of America}

The USA represents the beating heart for the central life blood and existence of Black Theology across the world. As we will see shortly, the academic conception of Black Theology is largely a North American story. The continued development of Black Theology emerges from the vast material and human resources of competitive, Black academic scholarship that emerges from the impressive American college system.

It is interesting to note, however, that for all the impressive developments of Black Theology in the USA, which for the most part remain unparalleled in other parts of the world, Black Theology has never been an identifiable, independent subject in its own right. To the best of my knowledge, there are no Professorial chairs in Black Theology. One cannot receive degrees in Black Theology. ${ }^{2}$ For the most part, Black Theology work in the USA has become part of the wider disciplines of Systematic and Constructive Theologies and Ethics. James H. Cone, the 'founding patriarch' of Black Theology the world over, plied his trade as a systematic theologian at Union Theology seminary; his protégé Dwight N. Hopkins occupies the post of Professor in Constructive Theology in the Divinity School at Chicago University. In the parallel discipline of Womanist Theology, arguably, its two leading exponents in terms of publications were the late Katie G. Cannon and Emile M. Townes, who are both ethicists.

None of the aforementioned researchers has specific academic nomenclatures that define them as black or womanist scholars in their own right. I am not suggesting that this is an error or a mistake of any kind, simply that it is indicative of the questionable status or identity of Black Theology in the

2.For a short period the University of Birmingham conferred a Master of Arts (MA) degree in Black Theology. The MA in Black Theology was pioneered by Emmanuel degree in Black Theology. The MA in Black Theology was pioneered by Emmanue Lartey, who at the time of its conception in the late 1990s was a senior lecturer in Pastoral Theology and Director of the Graduate Centre for Theology and Religion at the University of Birmingham. The MA was disbanded several years ago. 
academy. Most academic subjects create necessary forms of infrastructure and multi-formed apparel that constitutes the professional hinterland for the ongoing development of the discipline. So whether one is addressing ones' concerns to the fields of Ethics, or Pastoral Theology, it is clearly the case that for the discipline and the subject to flourish, scholarly guilds are erected, chairs are funded or endowed, publications are created and academic scholarly periodicals are developed.

In the USA, the nomenclature of 'Black Theology' is often contained within the larger, more generic enterprise of 'Black Church Studies' or 'Black Religion'. What is it about the naming of Black Theology as a specific self-named discipline in its own right that remains problematic or even contentious? In the USA, the struggle for Black Theology has emerged between the comparatively conservative or orthodox ${ }^{3}$ normative phenomenon of African American Christianity and the more transgressive and less confessionally bound African American religious studies. ${ }^{4}$ The former represents the position of the majority of African American churches that are unaware of or simply eschew any engagement with the seemingly dangerous and heterodox movement, that is, Black Theology. The latter reflects the intellectual nexus between a confessional, Christian church-related enterprise named Black Theology and the broader, macro-strains of African American religiosity, which seek a more expansive and perhaps less constrained form of discourse that transcends the bounded parameters of the Black Church.

My re-evaluations of the development of Black Theology in the USA have been shifted and informed by the death of James H. Cone (2018) and final memoir Said I Wasn't Gonna Tell Nobody: The Making of a Black Theologian. Cone's memoir was instructive in that he offers a subjective narrative to his life and the generative beginnings of Black Liberation Theology. Reading Cone's final book was not only hugely emotional, it was also very instructive. Cone's text takes us into the epistemological racism of the north American theological academy in the late 1960s. Many of Cone's more liberal critics were happy to consign the relevance of Black Theology to comparative disciplines of sociology and anthropology as opposed to theology. Therefore, Cone's decision to locate Black Theology firmly within the formal discipline of Systematic theology was a tactical move in order to ensure that this thematic approach to academic theology would not be marginalised or exorcised from the hinterland of 'mainstream' academic theology. I can now see, more clearly, the rationale for locating Black Theology squarely within the mainstream discipline of Systematic theology and Christian ethics, as opposed to being an independent intellectual undertaking in its own right.

3.All nomenclatures are problematic: I use these twin terms as ways of differentiating the positionality of Black Theology from more normative dimensions of Black God talk that might be defined in the United States of America, in more generic terms as 'African American Theology', which largely emanates and flourishes within what is often termed the Black Church. Whilst Black Theology emerges out of what I am often termed the Black Church. Whilst Black Theology emerges out of what I am terming conservative and orthodox African American Christianity, not everythin consistent with or indeed be perceived as being the former.

4.The challenge between the ideological presuppositions of Black Theology and the 4.The challenge between the ideological presuppositions of Black Theology and the more folk-orientated modulations of African American Christianity is discussed in
Andrews (2002). The nexus between Black Theology and African American Religious Andrews (2002). The nexus between Black Theology and African American
studies can be found in Pinn (2004) and Pinn and Hopkins (eds. 2004).

\section{Black Theology in South Africa ${ }^{5}$}

The next most important context in which Black Theology has been undertaken is that of South Africa. In South Africa, the development of Black Theology was in direct relationship with the phenomenon of apartheid (see Motlhabi 2009). Unlike such historic subjects as Christian Ethics or Church History, Black Theology in South Africa was perceived as a milieu that was a specific form of 'Contextual theology' ${ }^{6}$ whose mono-perspective of tackling the scourge of apartheid was its sole raison d'être. Once apartheid ended, many African scholars were quick to pronounce Black Theology as no longer having any primary reason to be. ${ }^{7}$ The temporality of Black Theology in South Africa can be seen in the twin fates of The Journal of Black Theology in South Africa and The Journal of Constructive Theology for South Africa. The former was the first ever self-named Black Theology periodical in the world and was produced by the staff of University of South Africa in Pretoria. In a private correspondence with one of its founders, I was informed that the journal ceased publication around 1998, some four years after the first universal democratic elections in the country, because of the lack of black religious scholars prepared to write for it. In comparison, The Journal of Theology for Southern Africa remains in print and has been a staple on the menu of theological reflection in the South African context since 1972.

The specificity of Black Theology in South Africa led to its being identified as a temporary, even aberrant, discipline whose existence was of utilitarian necessity and not a substantive theological practice in its own right. In more recent times, Motlhabi (2010) has posed the question as to whether Black Theology has now evolved into a broader and generic discipline of African theology. In using the term 'African theology', I am speaking about a Christian theology that is rooted in the African continent, which interrogates the intersectionality between theology, religious faith and practice and African cultures (see Michael 2013; Parratt 1995). African theology has focussed more on issues of inculturation and the nexus of Christianity and African religio-cultural traditions and practices that predate the missionary movements in Africa. The work of such luminaries as Lamin Sanneh (1989) has focussed on the nexus of Eurocentric mission Christianity and African religious and cultural traditions.

In this work, I am clear that there is a differentiation between the political radicalism of Black Theology, with its focus on

5.This is a deliberately short section out of respect for the editors of this work, whose social location as black religious scholars rooted within the South African context makes them much more accurate and authoritative speakers about the phenomenon of Black Theology in South Africa than myself. I trust nothing I write is deemed to be wildly inaccurate or painfully disrespectful. Any inaccuracies are solely my own and for that I apologise in advance.

6.It has been a matter of speculation by some advocates of Black Theology in South Africa that the early flourish of a radical, self-determined, black only, Africa-centred perspective on theology was by the mid-1980s and the drafting of the epoch making Kairos Document Kairos Document, replaced by the more emollient, liberal and "white-friendly' Speckman and Kaufmann (eds. 2001) 7.In this regard, see Gruchy, Koopman and Strijbos (eds. 2008). Many of the authors in
this argue that with the demise of apartheid, South Africa is now in the postthis argue that with the demise of apartheid, South Africa is now in the post-
liberation period that no longer necessitates the need for Black Consciousnessliberation period that no longer ne
inspired ideology of Black Theology. 
blackness and a critique of white supremacy, and that of cultural appropriation and affirmation of African traditions across the continent, against a backdrop of neoliberalism and globalisation. The two are linked in terms of the growing significance of 'Africanisation' and the necessity of reinstating African epistemology as the key to the continued development of the continent (see Tshaka 2019). I do not see the two as in opposition; rather, they are different sides of the same coin.

The critical question to be posed in light of the demise of Black Theology in South Africa relates to the nature of the discipline itself, namely, was it ever a 'proper', legitimate academic undertaking? The fact that it seems to have disappeared from the theological scene in South Africa would suggest that it was never conceived or perceived as a substantive discipline in its own right when compared to concretised enterprises such as Biblical Studies, Christian Ethics, Church History, Systematics and Pastoral Theology. This alleged demise of Black Theology in South Africa has occurred against a backdrop of the increased material poverty of black, African people in real economic terms and the alleged inaction of the African National Congress (ANC)-run government in addressing the scourge of human immunodeficiency virus and acquired immunodeficiency syndrome (HIV and AIDS) in the Southern African context (see Chigumira 2014).

One would have hoped that the obvious necessity for a sustained, liberative goal-orientated movement of Black Theology, intent on naming and challenging the structured and systemic abuses and injustices within this context, would not need further explication. It is interesting to note that the adopted nomenclature of 'Public Theology' within one of the more recent theological texts emerging from South Africa refuses to name the specific racial-ethnic identities of those who are deemed the workers and the endemic poor within the country (eds. De Gruchy, Koopman and Strijbos 2008). These generic categories mask the overwhelmingly black, African complexion of poverty in post-apartheid South Africa. The movement towards adopting alternative nomenclatures for undertaking critical and constructive theological reflection in South Africa is, I believe, a problematic one. I am not entirely clear how a departure from the iconic use of the term 'black' can aid the continued need for a radical liberation struggle in South Africa? It seems to me that the continued importance of the nomenclature of 'black' is precisely because it continues to unsettle and remains a difficult naming strategy with which to identify oneself.

At a time when the language of and the realities pertaining to blackness continues to be disparaged, to advocate the uncritical use of the nomenclature of African (into which oppressive structures and persons can also claim an identity) is to cede elements of the radical and iconoclastic agenda for the more mainstream position into which all elements can coalesce, even those whose commitment to systemic, transformative change has to be questioned. This brings me to my other concern, namely, how does the movement from
Black Theology to African theology not become a subtle movement towards a 'business as usual' policy where patriarchy and male privilege are re-inscribed under a rubric of 'tradition' and 'historical precedent'? These are substantive questions for black theologians in South Africa and are not ones that I can answer, but they need to be asked! (For more contemporary developments in Black Theology in South Africa, including wrestling with the impact of neo-liberalism and globalisation and the quest for Africanisation and decolonising the curriculum, see Boesak 2015, 2017, 2019; see also Tshaka 2019; Urbaniak 2019).

\section{Black Theology in Britain}

The third important context in which Black Theology is undertaken is in the UK. In my own context, Black Theology has often struggled, less in terms of the specific naming of itself as particular academic discipline in its own right (as in the USA) or from its ongoing retention as an intellectual discipline at all (as in South Africa), but rather, its difficulty has been in terms of definition. Whilst a number of black pastors and ministers were at the forefront of developing the nascent identity of Black Theology in Britain, there is no doubt that the first major work that purported to be Black Theology in Britain was undertaken by a white German woman, named Roswith Gerloff (1991). Gerloff's work, which dates back to the late 1980s, posited the notion that Black Theology was largely synonymous with Black Caribbean Pentecostalism, which had migrated to the UK, via the Caribbean, as part of the Windrush phenomenon. ${ }^{8}$ Gerloff in linking Black Theology in Britain to the demonstrable existence of 'Black-led Churches' made, to my mind, the major error of assuming that blackness of expression could be equated with substantive liberationist claims of blackness in terms of hermeneutics and theological method.

I remain puzzled that one could identify evangelical churches that largely operate with fundamentalist or literalist approaches to the biblical text and who eschew any sense of prioritising the essentiality of privileging the black experience as the point of departure over and above biblical and theological orthodoxy can be seen as the natural repository for Black Theology in Britain (this claim is made by a leading black Pentecostal Theologian R. David Muir 2010).

One of the central problems that have afflicted Black Theology, as a result of Gerloff's fine legacy (for articulating Black Christian studies and not Black Theology), is the difficulty of defining what is genuine or authentic Black Theology in Britain? In the UK, there has remained a continued belief that Black Theology is a discipline undertaken by all black people who might describe themselves as theologians or who undertake constructive talk about God. Elsewhere, I have argued that black religious

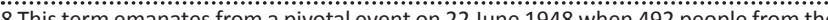
Caribbean arrived at Tilbury docks on the SS. Empire Windrush. These post-war Caribbean arrived at Tilbury docks on the SS. Empire Windrush. These post-war pioneers ushered in a wave of black migration to Britain from the Caribbean, which (for the most part) forms the basis of black African and Caribbean communities in Britain. For further information, see Phillips and Phillips (1999). 
scholars whose works reflect something of black Christian expression, but are not committed to deconstructing and reinterpreting the basic meaning of God in light of black experience and social existence, may be doing many meaningful and important things, but they are not doing Black Theology (see Reddie 2008).

Commenting specifically on the religious phenomenon Gerloff helped to usher into being (what I have termed black Christian religious experience as opposed to Black Theology in Britain), I state that (Reddie 2008):

[W]hen speaking of Black Christian religious experience, this term refers to the 'folk' orientated approach to Christian traditions which arise out of Black experiences, but which do not necessarily have a political or explicitly progressive and transformative agenda. Neither does this approach necessarily see Blackness as being a primary hermeneutical lens for reinterpreting the Christian faith, nor is it the case that one necessarily begins with black experience as the normative source for doing theology. (p. 20)

The problem lying at the heart of Black Theology in Britain is the assumption that simply being black or acknowledging one's blackness is seen as the benchmark for what constitutes Black Theology. Therefore, it is not uncommon to find individuals claiming an allegiance to the claims of Black Theology whilst still wanting to assert the exclusive primacy of the Bible as the only recognisable source for talking about God. Such individuals will resist the claims of women or Lesbian, Gay, Bisexual, Transgender (LGBTQ+) communities on the basis that the positionality and existential subjectivity of such persons for liberation are circumscribed by the Bible, whilst not recognising that such views are themselves inimical to the very notion of Black Theology. That in effect, Black Theology, whilst adhering to some of the elemental and experiential expressions of evangelical influenced worship and connectionality with individuative piety related to a personal God revealed in Christ, nevertheless departs from the doctrinal essentialism of a solely bibliocentric conception of the Christian faith.

In short, Black Theology remains a religio-political ideological movement that asserts a particular understanding of God in light of black suffering and oppression. It is not reducible to what all or any black person says about the faith, particularly those who would self-identify as black Evangelicals. This challenge presented to Black Theology can be found in the more recent publication of Aldred and Ogbo (eds. 2010), where, despite the continued challenges posed by such critical issues as patriarchy, interfaith (particularly the challenge of Islam) (Reddie 2009b) and sexuality, this text eschews any such engagement with any of the substantive transgressive issues that are high on the political agenda in the 21 st century.

At the heart of black Christianity is the positionality of Black Theology in Britain, which like all branches of the family termed 'theologies of liberation' is often characterised by its commitment to liberative praxis. The ongoing development of Black Theology in Britain has operated largely within the parameters of the Black Church, as opposed to the formal structures and scholarly hinterland of the academy. At the time of writing, there is only one academic institution presently teaching Black Theology in its curriculum - that is, the Queen's Foundation for Ecumenical Theological Education in Birmingham - where I worked for 13 years until I was made redundant by them in 2012. I would argue that what is being taught at Queen's at the time of writing under the auspices of 'The Centre for Black Theology' is not an authentic Black Theology of liberation. Rather, it is more accurately, what I would term 'Black Christian experience', namely, a mode of black theologising in which there is a cultural articulation of the faith that remains locked within neo-orthodox models of Christianity. This mode of theologising does not permit the reconceptualising of the faith in light of black existential experience and struggle when pitted against the dictates of the so-called Christian orthodoxy (Reddie 2008:20-25).

\section{Revitalising Black Theology}

One of the issues that has arisen from my reflections on the development of Black Theology concerns the limited prism often adopted by the discipline. One can see this tendency both in its depiction of black communities in the USA and the UK, and also within the historiographical development of the discipline itself.

One can see the aforementioned in terms of how Black Theology has reflected on black religious communities. In a great deal of the early Black Theology work, there was a tendency to see black communities as monolithic. It can be argued that Black Theology must show greater intent at deconstructing the inherent class bias between middle-class and working-class black people, particularly when it comes to respectability politics and who is affirmed and who is disparaged. My reflections on the development of Black Theology as a middle-class academic discipline highlight the need for solidarity amongst black peoples. Black Theology needs to reflect more deliberately on the middle-class norms of respectability that continue to weave its way through the discipline, often unintentionally evoking the normative positionality of white bourgeois sensibilities.

The challenge for Black Theology is expressed in the extent to which it has reified the middle-class-based concerns at legitimation and respectability. Black Theology has often worked on the presumption of homogeneity. Much less effort has been spent in looking at questions pertaining to class, gender, sexuality or differences in political outlook, amongst a few of the concerns in this area. Black Theology has often ignored class differences and the internalised, middle-class bias that is often secreted within the body politic of black communities in the UK and the USA. We can see this particularly in the case when scholars have spoken about black and black majority churches (see Andrews 2002; eds. Andrews \& Smith 2011; Crumpton 2014; Paris 1985). 
The lack of critical insight into the middle-class pretensions of black churches and the inherent anti-blackness and working-class prejudice remains prevalent in black theological discourse. One of the notable exceptions in this regard is (2012) monumental work Black Bodies and the Black Church: A Blues Slant. Douglas' (2012) work provides an unflinching, critical gaze on the Black Church in the USA and the internalised racism of many of its leading branches, particularly, those in the so-called progressive north. One can see this exemplified in its analysis of Southern Black Christianity, where the author establishes an existential tripartite, operational basis for black bodies in relationship with the Black Church, moving from aspirant middle-classorientated churches that eschewed the alleged emotionalism of southern Black Christianity to the religious formation of the latter in all its African retentive guises. The third formulation was the blues, which shared the unfortunate distinction of being hated by both sides of the black Christian divide (Douglas 2012:61-85).

Perhaps, the most telling example is the internalising of racialised hierarchies, what Douglas calls 'colourism' that existed within many Black churches, particularly those in the North. Consider this indictment on the sensibilities of churches supposedly providing an alternative socio-religious arena representing the counter-cultural values of the Kingdom of God. Douglas, writing on the absurdities of a pernicious colourism and the ingrained anti-black ethic that existed in some churches, states (Douglas 2012):

[S]till other black congregations hung a fine tooth comb at the entrance to be used. If the comb could not pass through the potential black worshipper's hair, then he or she would be denied entrance. (p. 97)

Our tendency to view black communities as monolithic has meant that the diverse range of experiences and values that exist within the overall whole tends to be either downplayed or ignored altogether. An uncomfortable truth that is noticeable in particular types of black religio-cultural discourse is the existence of a type of hierarchy of 'blackness'. This often takes its cue from the prevailing concerns in many black communities, themselves, where some people are judged as belonging in a more complete fashion than others.

There are many black people who have been accused of not 'really being Black' or not being 'Black enough' (Julien 1992). Scholars such as Michael Eric Dyson (1993), Kobena Mercer (1994) and, most notably, Victor Anderson (1995) have challenged us to see beyond the often-straight jacketed interpretations we place on black cultural expression and their accompanying lived experience. Anderson, in particular, has challenged the way in which black religious, cultural critics have wanted to acknowledge only the 'positive aspects' of black life, and have often sought over look or ignore those elements of which we are not so proud. As Anderson (1995:118-131) reminds us, we cannot all be saints, heroes and 'trailblazers'.

One of the challenges that have faced a number of black communities in the African Diaspora is the sense of wanting to 'put ones best on show' and to draw a discrete veil over those aspects that cause an element of embarrassment and unease within the community itself. An example of this monolithically defined way in which black religio-cultural scholars have reflected on black religious identities can be seen in the visceral shock that first emerged when stories pertaining to the inherent humanity and frailty of the Revd Dr Martin Luther King Jr began to emerge (Abernathy 1989). I remember a black community activist with whom I was friend at the time lamenting that 'why did they have to reveal all this? The man didn't deserve this!' Michael Eric Dyson's (1999) honest account of the life of Martin Luther King is an important example of dealing with the wholeness of human experience, and not just the edited highlights, but this work has still caused some anger and disappointment amongst some.

In a later book, the same author attempts a critical reassessment of the life of deceased rapper, Tupac Shakur. Dyson (2002) opens up new possibilities for us to see beyond the limited binaries of 'heroes' and 'villains', 'good people' and 'bad' ones. Life, culture and cultural expression are complex and often contradictory for those kinds of simplistic binaries (Beckford 2001).

Whilst the exercise I have described provides the experiential basis on which ordinary participants can gain insight into the cultural and sociopolitical issues replete with many black communities in the USA and the UK, its utility extends to the very historiography of Black Theology itself. This critical challenge facing Black Theology is one that explores the dangers of legitimation within the discipline in terms of its identity as primarily a subset of systematic theology within the theological academy developed and controlled by white EuroAmerican hegemony. As we have seen at an earlier juncture in this article, some have argued that, in the first instance, Black Theology only emerged because of the failings of others - one of the early white interlocutors with Black Theology was Helmut Gollwitzer (1979), who was a Professor of Systematic Theology at Free University of Berlin. He was one of a small number of white contributors to the groundbreaking first volume of the documentary history anthology edited by Gayraud Wilmore and James Cone, that is, the white power structures of empire and Christendom. Paraphrasing a celebrated quote from the famed African American religious and cultural critic, Victor Anderson (1995:86-93), is Black Theology dependent on the blackness that whiteness created?

The legitimation of Black Theology has been critiqued, with most alacrity, by Elonda Clay, in a special issue of Black Theology: An International Journal dedicated to the legacy of James H. Cone. Clay's essay offers a respectful but critical assessment of Black Theology on the occasion of the 40th anniversary of James Cone's groundbreaking text Black Theology and Black Power. Clay (2010) critiques the development of Black Theology in the USA as a static intellectual movement that has reified the tropes of liberation 
to a historic moment rooted in the 1960 s religio-cultural and sociopolitical epoch.

In a telling comment on the reified nature of Black Theology, Clay (2010) says:

$[I]$ posit that the original way in which the concept, heuristic, and signifier 'liberation' functioned in U.S. Black Liberation Theology, has by both form and content, been un/consciously resignified into a discourse of cultural legitimation. That is to say, while the use of 'liberation' had a particular importance for a specific historical moment (late 1960s), second- and thirdgeneration Black theologians have seemingly failed to rethink the heuristic of 'liberation' for changing conditions and contexts, which include postmodernity, post-Black Power/Civil Rights politics, post-industrialization, and the network society epoch. (pp. 310-311)

The antithesis of the legitimation of which Clay speaks is the commitment of Black Theology to reconnect with the popularist roots of the movement in the Garveyite era in the early decades of the last century and later in the Black nationalism of Albert Cleage. In this regard, the work of Chas Howard (2014), and later Jawanza Eric Clark (2012), is very significant in providing a critical nexus between epistemological innovation and praxiological change. Both scholars have sought to combine intellectual engagement in the furthering of the discipline with the commitment to root their ideas within the popular religio-cultural mass movements that represent the active engagement of ordinary black people in their respective milieus. In both of these respective studies, we see an expressed commitment to praxis-based contemporary movements that seek to move Black Theology beyond its often myopic reified obsession with its own intellectual status within the academy, rooted in the identity politics of the 1960s.

\section{Renewed spiritual liberative praxis and the legacy of Vuyani Vellem}

One of the key insights of Vuyani Vellem's brilliance was his emphasis on the embodied nature of African spirituality as the locomotive power of black people as opposed to the dictates of formal theologising (Vellem 2014). Taking onboard the insights of Vellem, I have sought to relocate the development of Black Theology in Britain in a manner informed by the epistemological insights of a form of dialectical spiritualities that reflect the Diasporan journeys of black Caribbean people from the African continent to the Caribbean via the African slave trade and then onto the UK, the so-called 'Mother Country', as economic migrants.

The lives of black people of the 'Windrush generation' were ones that sought to make sense of this layered reality to life in Britain by way of a rich diet of religio-cultural repertoire that sought to interrogate the surface realities of life by means of a subterranean framework of often concealed practices that critiqued the world of white normalcy for its veracity or lack of it. The faith of the 'Windrush generation' was part of a larger repertoire of religio-cultural experiences that frame the broader contours of this article. What that generation's faith exemplified was a complex, embodied matrix in which their lives evinced the dialectical negotiation between the evangelical Protestant version of Christianity and the subterranean religio-cultural patterns of African-derived religious sensibilities. The life of faith of that generation of Caribbean migrants moved simultaneously between both modes of being, holding them together, as complex forms of dialectical spiritualities.

The basis of this developing work is that Caribbean people are invariably never one thing or the other, but rather are complex matrices of multiple influences and perspectives. For many black, Caribbean people, their general theism and theology enable them to hold a dialectical perspective on reality.

The complex amalgam of black religious traditions and sensibilities falls within the theorised parameters outlined by scholars such as Albert Raboteau (1978) and Robert Hood (1990). Their work is characterised, in particular, by a pervasive sense of the work of the spirit(s) within black life. The spirit offers different ways of knowing (Johns 1998) and provides an alternative, parallel reality to the concrete nature of the immediate built (and invariably racist) environment that most commonly confronts us (see Beckford 2000:168-192). These alternative ways of knowing often operated as the subterranean mode of being that operated beneath the formalised adherence of Protestant evangelicalism underpinned by a faithful reading of the Bible, as the authoritative 'Word of God'. The existence and manifestation of the spirits in the lives of African people have been explored in an exemplary manner by Esther Acolatse (2014). Acolatse's work explores the pastoral implications of being immersed in a world of the pervasive presence of the spirits and the cognisance of Africans to issues of divination and deliverance ministries.

Acolatse (2014:32-71), writing as a reformed theologian, is aware of the tension within black religious and theological discourse surrounding the relationship between the spirits and the Holy Spirit. The latter is contained within a distinct Christian framework that is often seen as being an anathema to or simply distinct, separate and superior from the former (Paris 1995:27-57). In more recent times, ethnographic research by African scholars is exploring the complexities of this discourse (Sackey 2002).

Acolatse's theological perspective is more critical of the collapsing of Christian and other forms of spiritualities and finds this problematic. In my developing work of Black Theology in Britain, I am not abiding by such orthodox Christian strictures. Drawing on the work of Hood (1990), and, more recently, Stewart (2005), I will work with the clear intentionality that the spiritualities of black people extend way beyond the often constricting limitations of Hellenistic influenced orthodox Christianity. The constrictions of Hellenistic influenced orthodox Christianity for me lie in 
the assumptions around binary notions of being, namely, the demarcation between normative orthodoxy and the heterodox other. It seemed clear to me observing the Windrush generation that any simplistic notion of their religious identities and concomitant spiritualities being simple mono-perspectival trajectories was an erroneous one. The churches to which many of these individuals belonged, often Catholics, Anglicans, Baptists, Methodists and Reformed traditions, would like to believe that their religious identities were subsumed by attendance at orthodox, historic forms of western Christianity. However, there lay beneath the outer edifice of religious orthodoxy, ways of being and knowing that speak about alternative subjectivities that echo to an African-derived past.

The focus on a liberative spiritual praxis, one that is inspired by the radical discourse of Vuyani Vellem, is of great significance for the ways in which it becomes the means of creating a critical nexus between Black Theology and African theology. A focus on liberative spiritual praxis is a mode of Black theologising that centres on the lived religious experience of ordinary people of African descent that moves beyond the often remote theological abstractions of traditional black theologians working through the medium of systematic theology.

Therefore, in focussing on liberative spiritual praxis, identifying the elemental resources that can confer freedom agency for ordinary black people, this mode of Black Theology is one that can bridge the gap between selfidentified black theologians and African theologians. The result of this nexus is one that finds me able to juxtapose the works of Tinyiko Malueleke, Rothney Tshaka and Vuyani Vellem alongside the likes of Esther Acolatse and Dianne Stewart - the latter two are not self-identified as black theologians.

Focussing on liberative spiritual praxis is, I believe, the enduring genius of Vuyani Vellem. This methodological perspective on Black Theology provides the means by which the liberationist dimensions of this prophetic movement can be realised in the everyday Christian practice and religiosity of black people, whether they are living in South Africa, Great Britain or United States of America. Liberative spiritual praxis expressed in the form of subterranean African spiritualities is also a means of conferring dignity on those aspects of our African religious identities that have been often traduced by Eurocentric mission Christianity.

In the UK, for example, it has rarely been the case that the Windrush generation have acknowledged the alternate, subterranean nature of African spiritualities, within the context of the African-derived religions that provided the larger cosmological, epistemological framework that informed their lives. This dialectical, epistemological framing for the religiosity of African Caribbean people connotes the deepest ontological basis for apprehending the nature of their humanity. The complexity of Diasporan
African religiosity represents the core basis of what it means to be a black human being.

When Caribbean migrants came to Britain in the post-Windrush era (approximately 1948-1965) (Reddie 2003:14-20), they brought with them this legacy of spiritual wisdom from Africa via the Caribbean. Upon arrival in the UK, these people encountered a deluge of racism (Barton 2005), and what enabled many of them to cope with their experiences of rejection was a direct sense of God being with them - this 'God with them' being in the form of the spirit that offers alternative ways of interpreting one's experience and dealing with the reality of rejection and hurt (Reddie 2009a).

In short, black bodies, particularly those of the black proletariat of the Windrush generation, represent the alternative constructs for what constitutes Christian normality is Britain. In their evocation of the politics, faith and the theology of difference, they embody a critical resistance ethic to the blandishments of empire and its toxic memory and the neo-colonial constructs of imperial mission Christianity $^{9}$ that underpinned Brexit in the UK. They offer a truer vision of Christianity than the tendentious, narrow and restricted version that was all too happy to collude with white English nationalism and Brexit.

The importance of the Windrush generation lies in their embodied riposte to all of the worst socio-religious indicators that underpinned Brexit. The presence of the Windrush generation is one that represents an embodied Pentecost in which their role within the body politic of the nation symbolises the gifts of multiculturalism and the grandeur and beauty of difference. Black Christianity, for all its limitations in imbibing too many of the blandishments of imperial mission Christianity and the folly of many of the Windrush generation voting for Brexit, remains an essential form of resistance to the bounded limitations of white English nationalism in the UK.

The Windrush generation remains the embodied exemplar that reminds us that Christianity's identity must remain as the religion of the marginalised and dispossessed and not the conduit that massages the fragility of white privilege and entitlement. This new, alternative framing for the methodological outworking of Black Theology is essential if Black Theology is to become the radical, grassroots mass movement envisaged by the founders of the discipline in each context. If Black Theology is to become the socio-religious and political resource that seeks to empower and transform the lives of ordinary black people, then it must find a methodological point of departure that can enliven the consciousness of the grassroots

9.In using this term, I am speaking about a historical phenomenon in which there existed (and continues to this day) an interpenetrating relationship between European expansionism, notions of white superiority and the material artefact of the apparatus of Empire. This form of Christianity became the conduit for the the apparatus of Empire. This form of Christianity became the conduit for the
expansionist paradigms of Eurocentric models of Christianity in which ethnocentric notions of Whiteness gave rise to notions of superiority, manifest destiny and notions of Whiteness gave rise to notions of superiority, manifest destiny and
entitlement. For a helpful dissection of this model of Christianity, particularly, the British version of it, see Gorringe (2004) and Hull (2014). 
proletariat in South Africa, Great Britain or the USA. I believe that a turn towards liberative spiritual praxis is the means of doing so.

This work offers an alternative framing for Black Theology that challenges the class divide between the bourgeois middle-class concerns of some black people when juxtaposed with their working-class and dispossessed counterparts. In many respects, what I am proposing will have greater resonance in South Africa, a black majority country on the continent that was once the home for all Africans, as opposed to the USA and Great Britain, where black people are a part of a diaspora, in white majority countries. It is my hope that South Africa will be at vanguard for the radical repositioning of Black Theology as a movement of liberative spiritual praxis that will set the lead for the USA and Great Britain to follow. A liberative spiritual praxis changes the dynamics between the rich and the poor, formally educated and those with no formal learning, respectable and transgressive, as the emphasis moves away from systematic and doctrinal articulations to an affirmation of lived, spiritual transformation of ordinary people. The priority for Black Theology must always be an unequivocal commitment to the poorest and the most marginalised.

Working from within the Reformed tradition, Vuyani Vellem knew about and was committed to the notion of Christianity as a form of religiosity that should represent the stunted lives of those who are marginalised and oppressed. The lives of underprivileged black, African people in South Africa represent an alternative mode of lived religious expression and being than that propagated by the white missionaries. In my own work, inspired by Vuyani Vellem, I too have sought to reflect on black, African spirituality as a means of reflecting on their subterranean, religio-cultural internalisation of Africancentred, derived religious forms of retention, represent the embodied riposte to the tendentious blandishments of White Mission Christianity and its continued attempts to other the black body against a prevailing tide of normalised whiteness.

The genius, Vuyani Vellem, will be a constant reminder that Black Theology must remain committed to the embodied realities of ordinary black people and their lives of marginalisation and oppression in a world dominated by white privilege and entitlement.

\section{Acknowledgements Competing interests}

The author declares that he has no financial or personal relationships that may have inappropriately influenced him in writing this research article.

\section{Author's contributions}

I declare that I am the sole author of this research article.

\section{Ethical consideration}

This article followed all ethical standards for a research without direct contact with human or animal subjects.

\section{Funding information}

This research received no specific grant from any funding agency in the public, commercial or not-for-profit sectors.

\section{Data availability statement}

Data sharing is not applicable to this article as no new data were created or analysed in this study.

\section{Disclaimer}

The views and opinions expressed in this article are those of the author and do not necessarily reflect the official policy or position of any affiliated agency of the author.

\section{References}

Abernathy, R.D., 1989, And the walls came tumbling down, Harper and Row, New York, NY. Ackroyd, S., Lewis-Cooper, M. \& Muchopa, N., 2001, Strangers no more: Transformation through racial justice, The Methodist Church, London.

Ackroyd, S., Lewis-Cooper, M. \& Muchopa, N., 2005, Workers for the harvest: A process for equipping racial justice facilitators, The Methodist Church, London.

Acolatse, E.E., 2014, For freedom or bondage: A critique of African pastoral practices, Wm.B. Eerdmans, Grand Rapids, MI.

Aldred, J. \& Ogbo, K. (eds.), 2010, The Black Church in Britain, DLT, London.

Anderson, V., 1995, Beyond ontological blackness, Continuum, New York, NY.

Andrews, D.P., 2002, Practical theology for black churches, Westminster John Knox, Louisville, KY.

Andrews, D.P. \& Smith, R.L. Jr. (eds.), 2015, Black practical theology, Baylor University Press, Waco, TX.

Anyabwile, T.M., 2007, The decline of African American theology: From biblical faith to cultural captivity: From biblical faith to cultural accommodation, Intervarsity Press, Downers Grove, IL.

Barton, M.B., 2005, Rejection, resistance and resurrection, DLT, London.

Beckford, R., 2000, Dread and Pentecostal, SPCK, London.

Beckford, R., 2001, God of the Rahtid: Redeeming rage, DLT, London.

Boesak, A.A., 2015, Kairos, crisis, and global Apartheid: The challenge to prophetic resistance, Palgrave Macmillan, New York.

Boesak, A.A., 2017, Pharaohs on both sides of the blood-red waters: Prophetic critique on empire: Resistance, justice, and the power of the hopeful sizwe -A transatlantic, Cascade Books, Eugene, OR.

Boesak, A.A., 2019, Children of the waters of meribah: Black liberation theology, the miriamic tradition, and the challenges of twenty-first-century empire, Cascade Books, Eugene, OR.

Bradley, A.B., 2010, Liberating black theology: The Bible and the black experience in America, Crossways, New York, NY.

Carter, A.J., 2016, Black and reformed seeing god's sovereignty in the AfricanAmerican Christian experience, P\&R Publishing, Phillipsburg, PA.

Chigumira, G., 2014, 'Mary as a symbol of ispiration for the epowerment of Southern African Christian wmen dsproportionately ifected/afected by HIV and AIDS', Black Theology: An International Journal 12(2), 117-138.

Clark, J., 2012, Eric indigenous black theology, Palgrave Macmillan, New York, NY.

Clay, E., 2010, 'A black theology of liberation or legitimation?', Black Theology: An International Journal 10(3), 307-326. https://doi.org/10.1558/blth.v8i3.307

Coates, T-N., 2014, Between the world and me, Random House, New York, NY.

Cone, J.H., 2018, Said I wasn't gonna tell nobody: The making of a black theologian, Orbis Books, Maryknoll, New York, NY.

Crumpton, S.M., 2014, A womanist pastoral theology against intimate and cultural violence, Palgrave Macmillan, New York, NY.

De Gruchy, S., Koopman, N. \& Strijbos, S. (eds.), 2008, From our side: Emerging perspectives on development and ethics, Rozenberg, Amsterdam.

Douglas, K.B., 2012, Black bodies and the black Church: A blues slant, Palgrave Macmillan, New York, NY.

Dyson, M.E., 1993, Reflecting black: African American cultural criticism, University of Minnesota Press, Minneapolis, MN. 
Dyson, M.E., 1999, I may not get there with you: The true Martin Luther King, Jr, Simon and Schuster, New York, NY.

Dyson, M.E., 2002, Holler if you hear me: Searching for Tupac Shakur, The University of Pennsylvania Press, Pittsburgh, PA.

Eddo-Lodge, R., 2017, Why I'm no longer talking to white people about race, Bloomsbury, London.

Eze, E.C., 1997, Race and the enlightenment, Blackwell, Oxford.

Gerloff, R.I.H., 1991, A plea for British black theologies: The Black Church movement in Britain, vol. 1. and vol. 2, Unpublished PhD thesis, The University of Birmingham, Birmingham.

Gollwitzer, H., 1979, 'Why black theology?', in G.S. Wilmore \& J.H. Cone (eds.), Black theology: A documentary history, 1966-1979, pp. 152-173, Orbis, Maryknoll, New York, NY.

Gorringe, T.J., 2004, Furthering humanity: A theology of culture, Routledge, London.

Hood, R.E., 1990, Must god remain Greek: Afro-cultures and God-Talk, Fortress Press, Minneapolis, MN.

Hopkins, D.N., 2005, Being human, Fortress Press, Minneapolis, MN.

Howard, C.L., 2014, Black theology as a mass movement, Palgrave Macmillan, New York, NY.

Hull, J.M., 2014, Towards the prophetic church: A study of christian mission, SCM, London.

Johns, C.B., 1998, Pentecostal formation: A pedagogy among the oppressed, Academic Press, Sheffield.

Julien, I., 1992, 'Black is, black ain't: Notes on de-essentializing black identities', in G. Dent (ed.) Black popular culture, pp. 255-263, Bay Press, Seattle, WA

Mercer, K., 1994, Welcome to the Jungle: New positions in black cultural studies, Routledge, London.

Michael, M., 2013, Christian theology and African traditions, Wipf and Stock, Eugene,

Motlhabi, M., 2008, African theology/black theology in South Africa: Looking back moving on, University of South Africa, Pretoria.

Motlhabi, M., 2009, African theology/Black theology in South Africa: Looking back, moving on, Unisa Press, Pretoria.

Muchopa, N., 2001, Making a positive difference, The Methodist Church, London.

Muir, R.D., 2010, 'Theology and the Black Church', in J. Aldred \& K. Ogbo (eds.) The Black Church in Britain: Facing up to the 21st century, pp. 8-27, DLT, London.

Oluo, I., 2018, So you want to talk about race, Seal Press, Boston, MA.
Paris, P.J., 1985, The social teaching of the black Churches, Fortress Press, Philadelphia, PA. Paris, P.J., 1995 The Spiritualities of African peoples: The search for a common mora discourse, Fortress Press, Minneapolis, MN.

Parratt, J., 1995, Reinventing Christianity: African theology today, Wm. B. Eerdmans Publishing Co, Grand Rapids, MI.

Phillips, M. \& Phillips, T., 1999, Windrush: The irresistible rise of multi-racial Britain, HarperCollins, London.

Pinn, A.B., 2004, African American humanist principles: Living and thinking like the children of Nimrod, Palgrave Macmillan, New York, NY.

Pinn, A.B. \& Hopkins, D.N. (eds.), 2004, Loving the body: Black religious studies and the erotic, Palgrave Macmillan, New York, NY.

Raboteau, A.J., 1978, Slave religion, Oxford University Press, New York, NY.

Reddie, A.G., 2003, Nobodies to somebodies, Epworth Press, Peterborough.

Reddie, A.G., 2006, Black theology in transatlantic dialogue, Palgrave Macmillan, New York, NY.

Reddie, A.G., 2008, Working against the grain, Equinox, London.

Reddie, A.G., 2009a, 'A dialectical spirituality of improvisation: The ambiguity of black engagement with sacred texts', in A.B. Pinn (ed.), Black religion and aesthetics: Religious thought and life in Africa and the African Diaspora, pp.153-171, Palgrave Macmillan, New York, NY.

Reddie, R.S., 2009b, Black Muslims in Britain: Why are growing number of young Black people converting to Islam, Lion books, Oxford.

Sackey, B.M., 2002, 'Spiritual deliverance as a form of health delivery: A case study of the solid rock chapel international', Black Theology in Britain: A Journal of Contextual Praxis 4(2), 150-171.

Sanneh, L., 1989, Translating the message: The missionary impact on culture, Orbis Books, Maryknoll, New York, NY.

Speckman, M.T. \& Kaufmann, L.T. (eds.), 2001, Towards an agenda for contextual theology: Essays in honour of Albert Nolan, Cluster Publications, Pietermaritzburg.

Stewart, D.M., 2005, Three eyes for the journey: African dimensions of the Jamaican religious experience, Oxford University Press, New York, NY.

Tshaka, R.S., 2019, 'The advocacy for Africanity as justice against epistemicide', Black Theology: An International Journal 17(2), 132-149. https://doi.org/10.1080/1476 9948.2019.1627094

Urbaniak, J., 2019, 'Decolonisation as unlearning christianity: Fallism and African religiosity as case studies', Black Theology: An International Journal 17(3), 223-240.

Vellem, V., 2014, 'Spirituality of liberation: A conversation with African religiosity', HTS Teologiese Studies 70(1), 107-114. https://doi.org/10.4102/hts.v70i1.2752 